DOI:

\title{
Model Perancangan Aplikasi Pesantren Matic Pada Forum Pondok Pesantren Jawa Barat
}

\author{
Edi Komarudin ${ }^{1}$, Ramadhan S. Bahri ${ }^{2}$, D. F. Maulana ${ }^{3}$, A. R. Maulana ${ }^{4}$ \\ ${ }^{1}$ Universitas Islam Negeri Sunan Gunung Djati Bandung \\ Email: edikomarudin@uinsgd.ac.id
}

\section{Keywords: \\ Design Model, FPP \\ West Java, Application, Islamic Boarding School}

\section{Kata Kunci:}

Model Perancangan, FPP Jawa Barat, Aplikasi, Pesantren Matic

\begin{abstract}
Pesantren Matic application is a website-based application that provides features for recording financial statements and as a tool for business development for the West Java Boarding School Forum. With a website-based application, FPP West Java can start a business in the form of ustadz training and certification, boarding school management governance training and training in recording the pesantren's financial statements. The target of this program is Islamic boarding schools in Indonesia and especially West Java. The Business Model Canvas used explains that: key partners (Ministry of Religion of West Java Province, Indonesian Ulama Council, Islamic Boarding Schools), key activities (Financial Recording, Islamic Boarding School Training, Ustadz training \& certification), key resource (West Java Boarding School Forum), value proposition (Integrated Ministry of Religion, Indonesian Ulema Council), Customer Relationship (Advertising (promos and subscriptions)), Channels (Website, Social Media, Advertising), Customer Segments (Pondok Pesantren, Ustady), Cost Structure (Domain and Hosting Registration Fees)), Revenue Streams (Financial Records, Islamic Boarding School Training, Ustadz training \& certification).
\end{abstract}

\section{Abstrak}

Aplikasi Pesantren Matic adalah aplikasi berbasis website yang memberikan fitur untuk pencatatan laporan keuangan dan sebagai tools bagi pengembangan bisnis bagi Forum Pondok Pesantren Jawa Barat. Dengan aplikasi berbasis website, FPP Jawa Barat dapat memulai bisnis dalam bentuk pelatihan dan sertifikasi ustad\%, pelatihan tata kelola manajemen pesantren serta pelatihan pencatatan laporan keuangan pesantren. Target program ini adalah pesantren-pesantren di Indonesia dan khususnya Jawa Barat. Business Model Canvas yang digunakan menjelaskan babwa: key partners (Kementerian Agama Provinsi Jawa Barat, Majelis Ulama Indonesia, Pondok Pesantren), key activities (Pencatatan Keuangan, Pelatiban Pesantren, pelatiban \& sertifikasi ustad₹), key resource (Forum Pondok Pesantren Jawa Barat), value proposition (Terintegrasi Kementerian Agama, Majelis Ulama Indonesia), Customer Relationship (Iklan (promo dan langganan)), Channels (Website, Sosial Media, Iklan), Customer Segments (Pondok Pesantren, Ustady), Cost Structure (Biaya Registrasi Domain dan Hosting), Revenue Streams (Pencatatan Keuangan, Pelatiban Pesantren, pelatihan \& sertifikasi ustadz). 


\section{Pendahuluan}

Setiap orang pasti memiliki sosok untuk diteladani, dan bagi kami seorang muslim mempunyai teladan Rosulullah Pesantren adalah salah satu tempat diajarkannya Akhlaqul Karimah Rosulullah , yang tidak konsen diajarkan di sekolah-sekolah formal lain. Namun, kondisi pesantren-pesantren saat ini mulai kehilangan kepercayaannya oleh masyarakat, pesantren dianggap memiliki sistem pendidikan yang kolot dan klasik sehingga akhirnya pesantren diidentikkan dengan pilihan terakhir siswa yang tidak diterima di sekolah-sekolah negeri maupun perguruan tinggi. Hari Santri Nasional (HSN) yang diresmikan Presiden Joko Widodo sejak tahun 2015 dan diperingati setiap tanggal 22 Oktober memang memberikan dampak yang luar biasa untuk meningkatkan peminat Pondok Pesantren [1], namun itu belum sepenuhnya mengubah pandangan masyarakat secara menyeluruh karena pesantren-pesantren yang meningkat peminatnya, mereka juga meningkatkan kualitas pendidikan dan sarana prasarana [2]. Pandangan bahwa pesantren memiliki aturan yang ketat masih menjadi bahan pemikiran orang tua memasukkan anaknya [3].

Analisis market kami lakukan menggunakan google form dan disebarkan ke pimpinanpimpinan pondok pesantren, pengurus pondok pesantren, ustadz/ustadzah, orangtua santriwan/santriwati, santriwan/santriwati. Alhamdulillah dari google form yang disebar sejak tanggal 26 Maret sampai tanggal 30 Maret 2019 Jam 22.36 WIB mendapatkan 68 responden dengan rincian, sebagai berikut:

Tabel 1 Responden Analisis Market Aplikasi Pesantren Matic

\begin{tabular}{|l|l|}
\hline Pimpinan Pondok Pesantren & 25 responden \\
\hline Pengurus Pondok Pesantren & 17 responden \\
\hline Ustadz/ustadzah & 4 responden \\
\hline Santriwan/Santriwati & 8 responden \\
\hline Mahasiswa/pelajar & 5 responden \\
\hline Forum Pondok Pesantren & 3 responden \\
\hline Dosen/Pengajar & 3 responden \\
\hline Wiraswasta & 1 responden \\
\hline Lainnya & 2 responden \\
\hline Total & $\mathbf{6 8}$ responden \\
\hline
\end{tabular}

Dari responden-responden di atas didapatkan hasil 54 responden menyatakan bahwa aplikasi pesantren matic penting diterapkan di Forum Pondok Pesantren karena mampu menunjang kinerja FPP dalam menata pondok pesantren dan sisanya sebanyak 14 responden menyatakan belum tahu kalua belum dicoba.

Berdasarkan kondisi di atas kami dari Prodi Komputerisasi Akuntansi yang memang konsen dalam dunia pemograman dan akuntansi, dengan peran aplikasi sekaligus memenuhi tantangan dunia tentang Revolusi Industri 4.0 dan juga dalam upaya mensukseskan Sustainable Development Goals Indonesia akhirnya kami memutuskan membuatkan Aplikasi Pesantren Matic. Agar aplikasi ini menjadi solusi kami juga bekerja sama dengan Forum Pondok Pesantren Jawa Barat dan Kementerian Agama Seksi Pendidikan Diniyah dan Pondok Pesantren Kota Bandung (yang juga merupakan implementasi dari MoA (Memorandum of Agreement) point aktivitas pengabdian pada masyarakat) untuk mengintegrasikan aplikasi ini agar kebutuhan- 
kebutuhan Pesantren. Aplikasi Pesantren Matic ini juga sejalan dengan 5 poin dalam Program Pesantren Juara Pemprov Jawa Barat, yaitu program One Pesantren One Product, Membangun database sistem informasi manajemen pesantren, mengembangkan manajemen modern pesantren, standarisasi kurikulum pesantren dan penyetaraan alumni pesantren, penelitian dna pengumpulan manuskrip karya- karya ulama [4].

\section{Kerangka Teoritis}

\section{Perancangan}

Definisi perancangan dalam buku yang berjudul Sistem Informasi Manajemen yaitu sebagai berikut: "Perancangan adalah kemampuan untuk membuat beberapa alternatif pemecahan masalah" [5]. berikut:

Definisi lain dari perancangan dalam buku Sistem Informasi Akuntansi yaitu sebagai

"Perancangan mencakup perancangan logis dan fisik. Kegiatan pokok perancangan logis adalah melengkapi eksternal level schema dan menerjemahkan persyaratan data para pemakai dan program aplikasi ke dalam conceptual level schema. Perancangan fisik (Physical Design) adalah mengubah hasil rancangan konsep ke dalam struktur penyimpanan fisik" [6].

Berdasarkan definisi di atas, peneliti dapat menyimpulkan bahwa perancangan adalah membuat alternatif pemecahan masalah secara logis dan fisik.

\section{Forum Pondok Pesantren}

Forum pondok pesantren menurut Pedoman Dasar \& Pedoman Rumah Tangga FPP Jawa Barat menjelaskan bahwa:

"FPP Jabar adalah sebuah lembaga independen yang beranggotakan pimpinan pesantren, pengelola pesantren, praktisi pendidikan, pakar pendidikan dan pemerintah, tetapi bukan sebagai organisasi massa atau organisasi politik".

\section{Use-Case Diagram}

Definisi use-case dalam buku yang berjudul Analisis Perancangan Sistem Berorientasi Objek dengan UML adalah sebagai berikut:

"Use Case adalah deskripsi fungsi dari sebuah system dari perspektif pengguna. Use case bekerja dengan cara mendeskripsikan tipikal interaksi antara user (pengguna) sebuah system dengan sistemnya sendiri melalui sebuah cerita bagaimana sebuah system dipakai" [7].

Definisi lain dari use-case menurut buku Pemodelan Sistem Informasi Berorientasi Objek Dengan UML yaitu sebagai berikut: "use-case adalah bagian tingkat tinggi dari 
fungsionalitas yang disediakan oleh sistem. Dengan kata lain, use-case menggambarkan bagaimana seseorang menggunakan system" [8]. Berdasarkan definisi di atas, peneliti menyimpulkan bahwa diagram use-case merupakan deskripsi aksi-aksi yang dilakukan oleh sistem yang dikembangkan.

Berdasarkan buku Pemodelan Sistem Informasi Berorientasi Objek dengan UML yang peneliti baca, diagram use-case menyajikan interaksi antara use-case dan aktor, dimana aktor dapat berupa orang, peralatan atau sistem lain yang berinteraksi dengan sistem yang sedang dibangun [8]. Dalam buku yang berjudul Pemodelan Sistem Informasi Berorientasi Objek dengan UML, use-case menjelaskan apa yang sistem akan lakukan [8]. Untuk membangun sistem secara aktual memerlukan rancangan yang lebih spesifik. Spesifikasi ini ditulis dalam aliran kejadian (flow of events) yang meliputi:

"1. Deskripsi singkat

2. Kondisi

3. Aliran kejadian utama

4. Aliran kejadian alternatif

5. Kondisi awal dan kondisi akhir" [8].

Aliran kejadian berfungsi untuk menjelaskan langkah-langkah apa yang terjadi untuk menjalankan fungsionalitas dalam use-case. Ada 3 tipe aliran kejadian menurut buku yang berjudul Pemodelan Sistem Informasi Berorientasi Objek Dengan UML. yaitu sebagai berikut:

1. Aliran utama adalah skenario "happy day"

2. Aliran alternatif adalah penyimpangan dari aliran utama dan bukan sebagai kondisi salah

3. Aliran kesalahan (eror flow) adalah penyimpangan dari aliran utama atau aliran alternatif yang menyatakan kondisi eror [8].

Dalam penelitian ini, peneliti menggunakan aliran kejadian utama dalam proses pembuatan use-case nya.

\section{Informasi}

Definisi Informasi menurut Supriyati menjelaskan bahwa: "informasi adalah data yang telah diolah sehingga mempunyai manfaat dan arti bagi yang menerimanya" [9].

Berdasarkan definisi-definisi di atas dapat diambil simpulan bahwa informasi adalah kumpulan data yang diolah menjadi lebih berguna dan berarti sehingga menjadikan ilmu bagi yang menggunakannya.

\section{Metode}

1. Unit Analisis

Unit analisis adalah subjek atau tempat pengumpulan data selama proses analisis data. Peneliti melakukan penelitian pada FPP Jawa Barat.

2. Populasi 
Populasi adalah keselurahan bagian atas objek yang akan diteliti, dianalisis dan diambil simpulan. Populasi yang digunakan dalam penelitian ini adalah semua formulir/dokumen dari transaksi keuangan maupun pelaksanaan program kerja tahun 2011 sampai tahun 2018.

\section{Sampel}

Sampel adalah sebagian objek dari populasi yang akan diamati. Pada penelitian ini sampel yang digunakan adalah semua formulir/dokumen dari transaksi keuangan maupun pelaksanaan program kerja tahun 2017-2018.

\section{Objek Penelitian}

Objek penelitian dalam penelitian ini adalah model perancangan aplikasi pesantren matic pada Forum Pondok Pesantren Jawa Barat.

\section{Metode Penelitian}

Metode penelitian adalah tatacara ilmiah melaksanakan penelitian untuk mendapatkan data dengan tujuan dan kegunaan tertentu. Metode penelitian yang digunakan peneliti adalah metode penelitian deskriptif, eksploratif, dan survei.

\section{Teknik Pengumpulan Data}

Teknik pengumpulan data yang digunakan adalah wawancara dengan Ketua Forum Pondok Pesantren Jawa Barat, data primer yang digunakan adalah dokumen / catatan dari Forum Pondok Pesantren Jawa Barat, sedangkan data sekunder berasal dari jurnal literatur, buku dan peraturan pemerintah.

\section{Metodologi Pengembangan Sistem}

Metodologi pengembangan sistem adalah serangkaian langkah untuk mengembangkan suatu sistem informasi. Metodologi pengembangan sistem yang digunakan peneliti gunakan adalah metodologi berorientasi objek.

\section{Model Pengembangan Sistem}

Model pengembangan sistem yang digunakan peneliti adalah model pengembangan sistem Rapid Application Development (RAD).

\section{Hasil Dan Pembahasan}

Aplikasi Pesantren Matic adalah aplikasi berbasis website yang dibuat untuk memaksimalkan program kerja Forum Pondok Pesantren Jawa Barat dalam mengembangkan pondok pesantren dari sisi Manajemen Pondok Pesantren, Pencatatan keuangan, produk unggulan pesantren, legalitas pesantren, inventarisasi asset, serta santri dengan konsep santripreneur. Aplikasi ini diharapkan mampu menjadi solusi dari permasalahan pesantren saat ini dan mampu menunjang terwujudnya pesantren sebagai unit pendidikan utama yang mandiri dan kuat dalam ekonomi dan Teknologi Informasi dan Komunikasi sehingga menjadi pilihan utama orang tua dalam pendidikan anak-anaknya dengan menampilkan sisi pesantren yang unggul dalam IMTAK (Iman dan Takwa), IPTEK (Ilmu Pengetahuan dan Teknologi) serta berjiwa entrepreneurship. 
Pada Forum Pondok Pesantren Jawa Barat

\section{Spesifikasi Produk Aplikasi Pesantren Matic}

Tabel 1.2 Spesifikasi Produk Aplikasi Pesantren Matic

\begin{tabular}{|c|c|}
\hline Nama Aplikasi & Aplikasi Pesantren Matic \\
\hline Basis Aplikasi & Website \\
\hline Logo Aplikasi & \\
\hline Slogan & $\begin{array}{l}\text { "FAST (Fathonah, Amanah, Sidiq, Tabligh) for Pondok } \\
\text { Pesantren" }\end{array}$ \\
\hline Integrasi Aplikasi & $\begin{array}{ll}\text { - } & \text { Terintegrasi Forum Pondok Pesantren Jawa Barat } \\
\text { - } & \text { Terintegrasi Kantor Kementerian Agama Kota Bandung } \\
& \text { Seksi Pendidikan Diniyah dan Pondok Pesantren } \\
\text { - } & \text { Terintegrasi Majelis Ulama Indonesia Provinsi Jawa Barat }\end{array}$ \\
\hline
\end{tabular}

\section{Tujuan}

Menjadi fasilitator dibidang teknologi informasi dan komunikasi dalam mengembangkan Lembaga Pondok Pesantren digital yang professional baik di wilayah, nasional maupun internasional untuk membangun kemandirian, kekuatan dan peningkatan kualitas pembelajaran yang berbasis TIK dibidang keagamaan dalam peningkatan pemberdayaan ekonomi dengan berlandaskan IMTAK (Iman dan Takwa), IPTEK (Ilmu Pengetahuan dan Teknologi) yang bersifat "FAST (Fathonah, Amanah, Sidiq, Tabligh) serta berjiwa Technoprenersip.

\section{Potensi}

- Membangun kerjasama dengan Forum Pondok Pesantren Jawa Barat dibuktikan dengan membuat MoU dan MoA (Bukti Terlampir) memiliki pengaruh dalam pemberdayaan Pondok Pesantren Jawa Barat, untuk menjamin bahwa Pesantren Matic adalah aplikasi terintegrasi dan memenuhi kebutuhan Pondok Pesantren.

- Membangun kerjasama dengan Forum Pondok Pesantren Kota Bandung dibuktikan dengan membuat MoU dan MoA.

- Membangun kerjasama dengan Kantor Kementerian Agama Kota Bandung dengan membuat MoU dan MoA Kantor Kementerian Agama Kota Bandung, (Bukti Terlampir). 
- Mendapatkan dukungan dari Majelis Ulama Indonesia wilayah Jawa Barat.

- Jawa Barat dapat dijadikan percontohan untuk terbentuknya Forum Pondok Pesantren di Provinsi lain di Indonesia.

- Sejalan dengan program Pesantren Juara dari Pemprov Jawa Barat.

- Sebagai Solusi dalam menghadapi Revolusi Industri 4.0 dan Menyiapkan diri dalam menghadapi Sustainable Development Goals (SDGs).

\section{Visi}

Menjadi Penyedia sarana layanan Teknologi Informasi dan Komunikasi yang berguna untuk Media Komunikasi, Publikasi, dan Pertanggungjawaban secara digital untuk Pondok Pesantren baik di Wilayah Jawa Barat, Indonesia dan Internasional dengan berlandaskan IMTAK (Iman dan Takwa), IPTEK (Ilmu Pengetahuan dan Teknologi) yang bersifat "FAST (Fathonah, Amanah, Sidiq, Tabligh) serta berjiwa Technoprenersip.

\section{Misi}

- Menggunakan teknologi informasi dan komunikasi berbasis website dan internet secara tepat.

- Membuat kesetaraan Lembaga pondok pesantren di bidang legalitas dan kurikulum pendidikan di bidang Ilmu Keagamaan dan Ilmu Pendidikan yang sesuai dengan standar nasional di Indonesia..

- Sebagai falisitas matic yang berguna untuk pesantren dalam Media Komunikasi, Publikasi, dan Pertanggungjawaban secara digital untuk Pondok Pesantren baik di Wilayah Jawa Barat, Indonesia dan Internasional

- Membuka kesempatan kepada setiap Pondok Pesantren untuk mengenalkan Pondok Pesantren dan produk unggulannya.

- Sebagai fasilitator link untuk menyiapkan produk unggulan pesantren dan santri ke Halal Center Wilayah Jawa Barat.

- Sebagai fasilitator untuk para santri prener agar memiliki jika Santri Technoprership. 
Edi Komarudin, Ramadhan S. Bahri, D. F. Maulana,

A. R. Maulana

Model Perancangan Aplikasi Pesantren Matic

Pada Forum Pondok Pesantren Jawa Barat

- Sebagai Fasilitator untul para umat islam yang tetap ingin belajar kajian ilmu agama yang memiliki keterbatasan waktu.
Jurnal @ is The Best Vol. 04 No. 01. Juni 2019: Hal 351-365

P-ISSN : 2252-9853 r memiliki keterbatasan waktu. 
Business Model Canvas Aplikasi Pesantren Matic

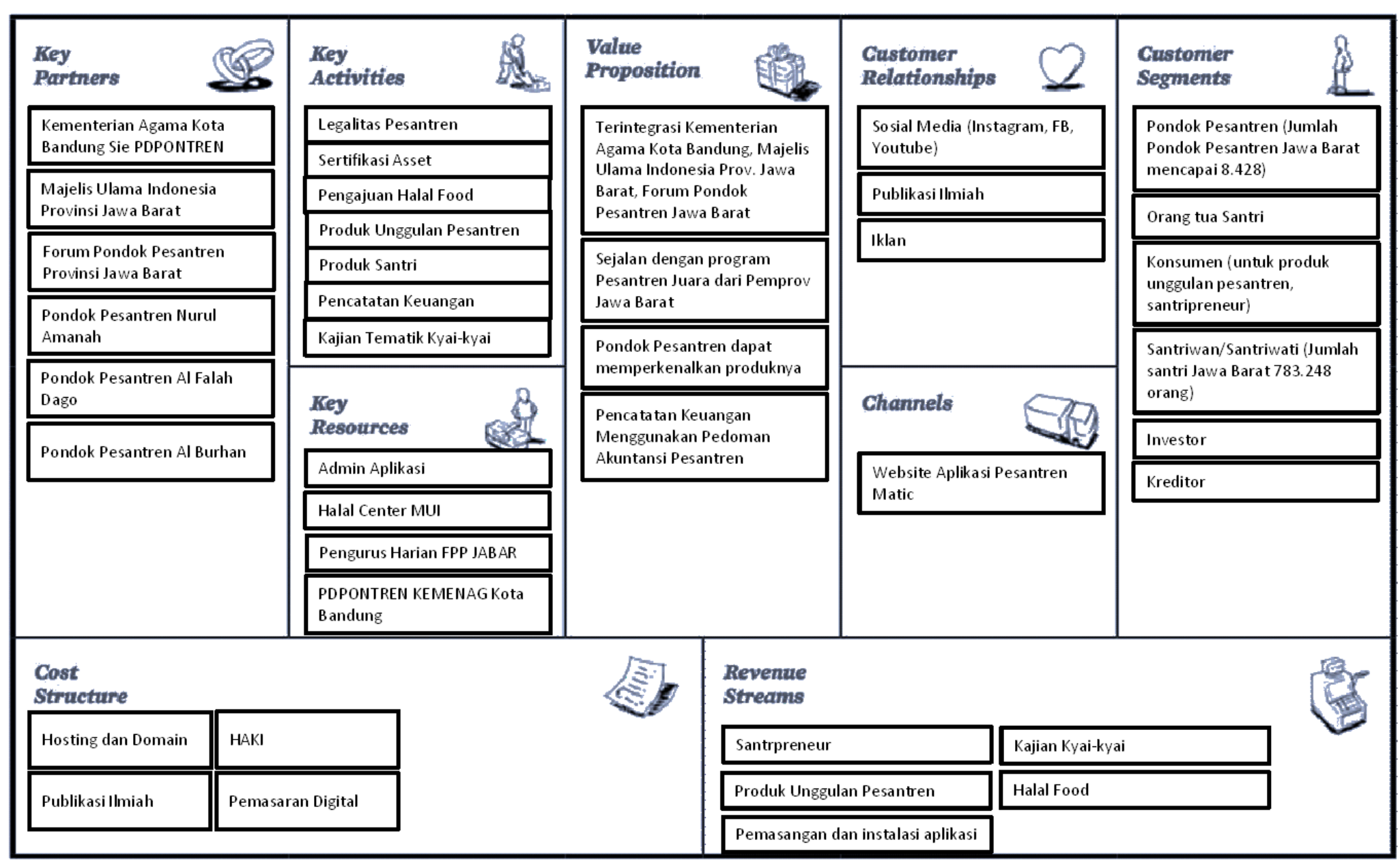

Gambar 1 Business Model Canvas Aplikasi Pesantren Matic 


\section{Fitur Aplikasi}

Fitur-fitur yang disediakan diaplikasi ini adalah sebagai berikut:

1. Home

Home adalah fitur yang menyediakan berita-berita kegiatan (FPP, Pesantren, Kementerian Agama, MUI).

2. Daftar

Daftar adalah fitur untuk membuat akun, tersedia sebagai:

- Pondok Pesantren

- Santripreneur

- Orang tua Santri

- Konsumen

3. Login

Login adalah fitur yang menyediakan hak akses untuk:

- Admin

Hak aksesnya meliputi maintenance aplikasi, notifikasi sistem dan bantuan berkaitan dengan aplikasi.

- Forum Pondok Pesantren

Hak aksesnya meliputi:

$\checkmark \quad$ Input/update data dan profil FPP

$\checkmark$ Proses permintaan inventarisasi asset

$\checkmark$ Dashboard data Pondok Pesantren, Kyai-kyai, Ustadz/Ustadzah, Santri-santri, dan produk unggulan pesantren.

$\checkmark$ Pencatatan Transaksi

$\checkmark$ Tampilan Jurnal Umum, Buku Besar Umum, Neraca Saldo dan Laporan Keuangan (Laporan Aktivitas, Laporan arus kas, laporan posisi keuangan).

$\checkmark$ Update berita FPP (Pelatihan Pesantren, Kader Pimpinan, Manajemen Pengurus Pesantren)

$\checkmark$ Logout

- Majelis Ulama Indonesia

Hak akses aplikasi:

$\checkmark$ Input/update data MUI

$\checkmark$ Input Kajian

$\checkmark$ Proses pengjuan halal food

$\checkmark$ Update Berita MUI (Halal Food, Fatwa, dll)

$\checkmark$ Logout

- Kementerian Agama Seksi Pendidikan Diniyah dan Pondok Pesantren

Hak akses aplikasi:

$\checkmark$ Input/update data Kemenag

$\checkmark \quad$ Update berita Kemenag

$\checkmark$ Proses permintaan legalitas pesantren

$\checkmark$ Logout

- Pondok Pesantren

Hak akses aplikasi:

$\checkmark$ Input/update data dan profil Pondok Pesantren

$\checkmark$ Input/update Produk Unggulan Pesantren

$\checkmark$ Input/update data santri

$\checkmark$ Pengajuan inventarisasi asset

$\checkmark$ Pengajuan Legalitas Pesantren 
$\checkmark$ Pencatatan Transaksi

$\checkmark$ Tampilan Jurnal Umum, Buku Besar Umum, Neraca Saldo dan Laporan Keuangan (Laporan Aktivitas, Laporan arus kas, laporan posisi keuangan).

$\checkmark$ Update berita Pondok Pesantren

$\checkmark$ Logout

- Santri

Hak akses aplikasi:

$\checkmark$ Input/update produk santri

$\checkmark$ Proses transaksi

$\checkmark$ Data produk

$\checkmark$ Logout

- Orang tua Santri

Hak akses aplikasi:

$\checkmark$ Tampilan data santri

$\checkmark$ Tampilan data kurikulum pesantren

$\checkmark$ Tampilan data pembayaran santri

$\checkmark$ Logout

- Konsumen

$\checkmark$ Beli produk pesantren

$\checkmark$ Beli produk pesantren

4. Bantuan

Logout

Bantuan adalah fitur untuk mengetahui cara mengoperasikan aplikasi.

5. Tentang Kami

Berisi informasi mengenai aplikasi pesantren matic.

6. Kontak

Berisi informasi mengenai kontak yang bisa dihubungi.

7. Profil

- Tampilan Profil FPP

- Tampilan Profil Pondok Pesantren

- Tampilan Profil MUI

- Tampilan Profil Kemenag

8. Produk

- Pengajuan Legalitas Pesantren

- Pengajuan Inventarisasi Asset

- Pengajuan Halal Food

- Produk Unggulan Pesantren

- Produk Santri (Santripreneur) 
Model Perancangan Aplikasi Pesantren Matic

P-ISSN : 2252-9853

Pada Forum Pondok Pesantren Jawa Barat

\section{Use Case Diagram}

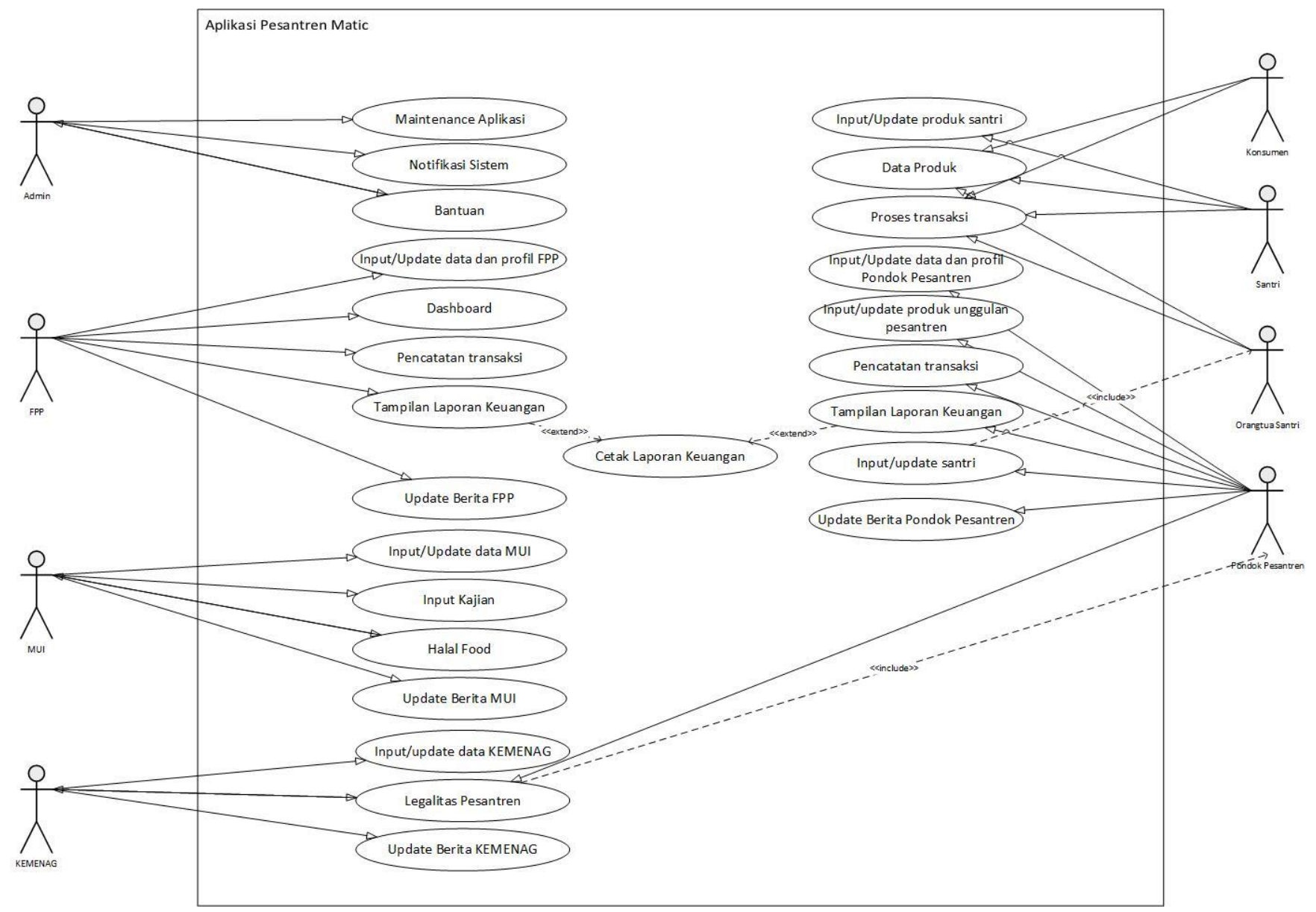

Gambar 2 Use Case Diagram 


\section{Arsitektur Jaringan Aplikasi Pesantren Matic}

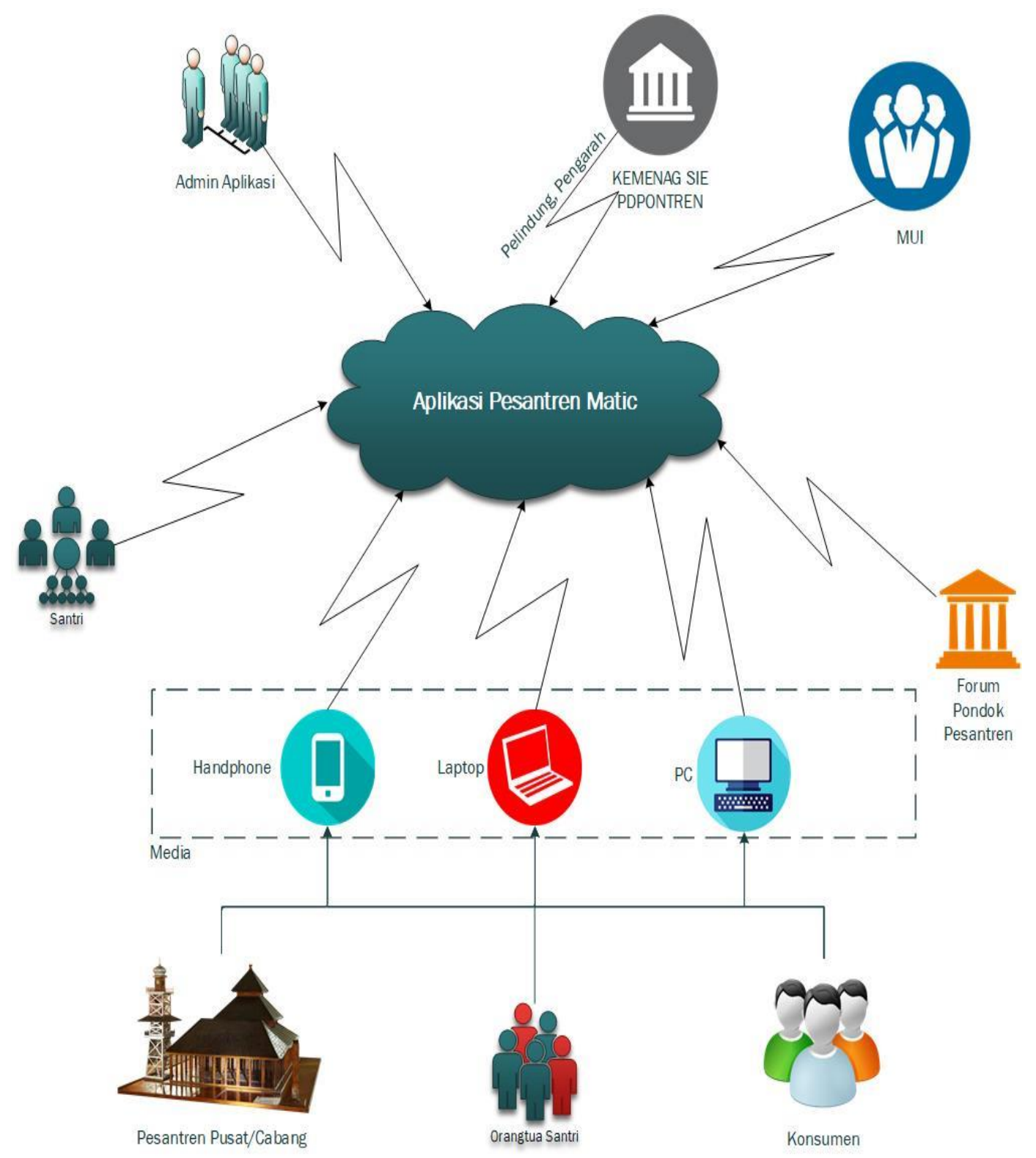

Gambar 3 Arsitektur Jaringan Aplikasi Pesantren Matic

\section{Manajemen Operasional}

Manajemen operasional Pesantren Matic merupakan perencanaan pelaksanaan dan pengendalian operasi yang mengkonversi sumber daya menjadi sebuah program aplikasi yang menerapkan strategi bisnis. Berikut aspek yang saling terkait dalam manajemen operasional yang dilakukan:

a. Aspek perencanaan aplikasi Pesantren Matic

- Perencanaan sistem aplikasi yang akan dirancang, yaitu aplikasi Pesantren Matic tentang pemberdayaan pesantren.

- Perencanaan fasilitas dan penentuan harga jual dari fasilitas yang akan diberikan.

- Perencanaan market aplikasi, yaitu FPP Jawa Barat dan Pondok Pesantren Jawa Barat. 
b. Aspek perancangan dan pengembangan aplikasi Pesantren Matic

- Perancangan aplikasi Pesantren Matic, mulai dari pembuatan aplikasi, percobaan aplikasi, serta perbaikan dan pemeliharaan aplikasi.

- Pengembangan aplikasi Pesantren Matic

c. Aspek pengujian dan implementasi

- Menguji aplikasi tanpa memerhatikan koding, hanya input dan outputnya saja.

- Mengintegrasi metode desain test cases software ke dalam suatu rangkaian.

- Indikator Penilaian IT

Tabel 3 Software System Attributes

\begin{tabular}{|l|l|}
\hline \multicolumn{1}{|c|}{ Parameter } & \multicolumn{1}{|c|}{ Requirement } \\
\hline $\begin{array}{l}\text { Availability } \\
\text { (tersedianya) }\end{array}$ & $\begin{array}{l}24 \mathrm{jam} \text { nonstop, kecuali ada maintenance / perbaikan } \\
\text { sistem. }\end{array}$ \\
\hline $\begin{array}{l}\text { Reliability } \\
\text { (keandalan) }\end{array}$ & Kegagalan yang ditolerir sekitar 5\%. \\
\hline Ergonomy & Sistem informasi ini harus user friendly. \\
\hline $\begin{array}{l}\text { Portability } \\
\text { (portabilitas) }\end{array}$ & $\begin{array}{l}\text { Aplikasi ini berjalan pada platform atau sistem operasi } \\
\text { apa saja yang mendukung aplikasi berbasis web. }\end{array}$ \\
\hline Memory & Minimum memory 64 MB. \\
\hline Response Time & Tidak lebih dari 3 detik. \\
\hline $\begin{array}{l}\text { Security } \\
\text { (keamanan) }\end{array}$ & $\begin{array}{l}\text { Login } \\
\text { Bahasa Komunikasi }\end{array}$ \\
\hline $\begin{array}{l}\text { Menggunakan bahasa Indonesia, kecuali ada } \\
\text { penambahan fasilitas untuk menggunakan bahasa lain. }\end{array}$ \\
\hline
\end{tabular}

- Kebutuhan antarmuka dalam program ini antara lain adalah kebutuhan perangkat keras berupa Personal Computer (PC) berupa Central Processing Unit (CPU), mouse, keyboard, monitor, dimana perangkat PC harus terhubung dengan jaringan intranet dan internet, sehingga membutuhkan Local Area Network (LAN) Card. Sedangkan untuk kebutuhan perangkat lunak yang harus disediakan adalah berupa sebuah web browser seperti Internet Explorer, Mozilla Firefox, dan sebagainya untuk menjalakan aplikasi berbasis web.

d. Evaluasi 
Edi Komarudin, Ramadhan S. Bahri, D. F. Maulana, A. R. Maulana

Model Perancangan Aplikasi Pesantren Matic

Pada Forum Pondok Pesantren Jawa Barat

\section{Konversi Sistem}

Aplikasi ini dapat digunakan dengan baik minimal memenuhi komponen-komponen berikut:

Table 4 Konversi Sistem

\begin{tabular}{|c|c|c|}
\hline No. & Komponen Sistem & Keterangan \\
\hline 1 & Hardware & $\begin{array}{l}\text { Prosesor: Pentium II } \\
\text { RAM: } 64 \mathrm{MB} \\
\text { Harddisk: } 2 \mathrm{~GB} \\
\text { VGA Card: } 4 \mathrm{MB}\end{array}$ \\
\hline 2 & Software & $\begin{array}{l}\text { Bisa diakses dalam semua software browser, yang } \\
\text { populer dan banyak digunakan adalah } \\
\text { - Mozilla Firefox } \\
\text { - Google Chrome } \\
\text { - Dolphin } \\
\text { - Opera } \\
\text { - UC } \\
\text { - CM } \\
\text { - Internet Explorer } \\
\text { - DU Browser }\end{array}$ \\
\hline 3 & Brainware & $\begin{array}{l}\text { - Admin Aplikasi } \\
\text { - Forum Pondok Pesantren } \\
\text { - Majelis Ulama Indonesia } \\
\text { - Kementerian Agama Seksi Pendidikan Diniyah dan } \\
\text { Pondok Pesantren } \\
\text { - Pondok Pesantren } \\
\text { - Santri } \\
\text { - Orangtua Santri } \\
\text { - Konsumen }\end{array}$ \\
\hline 4 & Prosedur & $\begin{array}{l}\text { - Prosedur pengajuan legalitas pondok pesantren } \\
\text { - Prosedur Halal MUI } \\
\text { - Prosedur inventarisasi asset } \\
\text { - Prosedur pencatatan laporan keuangan } \\
\text { - Prosedur transaksi produk unggulan pesantren } \\
\text { - Prosedur transaksi santriprenuer }\end{array}$ \\
\hline 5 & Database & Menggunakan database MySQL \\
\hline
\end{tabular}

Jurnal @ is The Best Vol. 04 No. 01. Juni 2019: Hal 351-365

P-ISSN : 2252-9853 


\begin{tabular}{|c|l|l|}
\hline 6 & $\begin{array}{l}\text { Teknologi } \\
\text { Jaringan } \\
\text { Telekomunikasi }\end{array}$ & $\begin{array}{l}\text { Menggunakan geografi jaringan Local Area Network } \\
\text { (LAN) }\end{array}$ \\
\hline
\end{tabular}

\section{Penutup}

Adanya model perancangan ini diharapkan pondok pesantren yang ada di wilayah Jawa Barat dapat terintegrasi dan bersinergi dalam mencapai tujuan untuk tetap survive di era revolusi industri 4.0 dengan standarisasi yang dilakukan oleh kementerian agama di wilayah kota dan provinsi dalam mendukung tujuan pesantren. Selain itu model perancangan ini diharapkan dapat menjadi fasilitator untuk mewujudkan peningkatan perekonimian di pondok pesantren yang ada di wilayah Jawa Barat.

\section{DAFTAR PUSTAKA (12pt bold Styles Heading 1)}

[1] https://www.pikiran-rakyat.com/jawa-barat/2018/10/22/hari-santri-sukses-ubahpandangan-masyarakat-terhadap-pesantren-431996

[2] https://nasional.tempo.co/read/263263/meningkat-peminat-pendidikan-pondok-pesantrendi-jawa-timur $/$ full\&view $=$ ok

[3] http://www.nu.or.id/post/read/79529/salah-kaprah-anggapan-sebagian-masyarakat-terkaitaturan-pesantren

[4] https://www.pikiran-rakyat.com/jawa-barat/2018/12/11/pemberdayaan-pesantrengubernur-jabar-lauching-one-pesantren-one-product

[5] A. Susanto, Sistem Informasi Manajemen. Bandung: Lingga Jaya, 2013

[6] Krismiaji, Sistem Informasi Akuntansi. Yogyakarta: UPP AMP YKPN, 2010.

[7] Munawar, Analisis Perancangan Sistem Berorientasi Objek dengan UML (Unified Modeling Language), November 2. Bandung: Informatika, 2018.

[8] Sholiq, Pemodelan Sistem Informasi Berorientasi Objek Dengan UML. Yogyakarta: Graha Ilmu, 2006.

[9] Supriyati and D. M. Rizky, "Model Perancangan Sistem Informasi Akuntansi Budidaya Perikanan Berbasis SAK EMKM dan Android," @is Best J., vol. 3, no. 2, pp. 301-316, 2018. 